\title{
Donor Deferral Rates after the Implementation of a New German Blood Donor Questionnaire
}

\author{
Michael Müller-Steinhardt ${ }^{a, b *}$ Christian Weidmann ${ }^{c *}$ Markus Wiesneth ${ }^{a, d} \quad$ Eberhard Weck $^{a, e}$ \\ Erhard Seifried ${ }^{\mathrm{a}, \mathrm{e}}$ Joachim Brade ${ }^{\mathrm{f}}$ Harald Klüter $^{\mathrm{a}, \mathrm{b}}$ \\ a German Red Cross Blood Service Baden-Württemberg - Hessen, \\ ${ }^{\mathrm{b}}$ Institute of Transfusion Medicine and Immunology, \\ ${ }^{c}$ Mannheim Institute of Public Health, Medical Faculty Mannheim, University of Heidelberg, Mannheim, \\ ${ }^{\mathrm{d}}$ Institute of Clinical Transfusion Medicine and Immunogenetics, Medical Faculty University of UIm, Ulm, \\ ${ }^{\mathrm{e}}$ Institute of Transfusion Medicine and Immunohematology, Medical Faculty Johann Wolfgang Goethe University Frankfurt, \\ ${ }^{f}$ Department of Medical Statistics and Biomathematics, Medical Faculty Mannheim, University of Heidelberg, Mannheim, Germany
}

\section{Keywords}

Blood donor questionnaire · Blood donor deferral .

Blood donation risks

\section{Summary}

Background: The implementation of a new national German blood donor questionnaire was proposed to improve donor and recipient safety. Methods: We compared deferral/exclusion rates of whole blood donors before (May 2010, $n=64,735$ ) and after (May 2011, $\mathrm{n}=71,687$ ) the implementation of a new blood donor questionnaire. Considering seasonal variations, analysis was performed with respect to collection site (mobile vs. fixed), sex, donor status (first-time vs. repeat), age, and the frequencies of sexual risk behavior and other reasons for deferral. Results: We observed a statistically significant increase $(p<0.001)$ of the overall deferral/exclusion rate from 6.2 to $8.1 \%$, irrespective of type of collection site (fixed: from 6.0 to $8.5 \%$; mobile: from 6.2 to $8.0 \%$ ), sex (females: from 7.5 to $9.9 \%$; males: from 5.1 to $6.6 \%$ ), donor status (first-time donors: from 19.7 to $24.7 \%$; repeat donors: from 4.6 to $6.3 \%$ ) or age (18-29 years: from 9.1 to $11.7 \%$; $60-71$ years: from 5.1 to $6.6 \%)$. Confidential self-exclusion increased from 0.08 to $0.14 \%$ ( $p<0.001$ ). Besides risk behavior, various medical reasons could be identified that explain this increase. Conclusions: The new blood donor questionnaire resulted in an increased deferral/exclusion of all donor groups. Thus the impact on future blood supply must be considered carefully, and long-term studies and investigation of donor acceptance will be needed.

*Both authors contributed equally to this work.

\author{
Schlüsselwörter \\ Blutspenderfragebogen · Blutspenderzurückweisung · \\ Blutspenderisiken
}

\section{Zusammenfassung}

Hintergrund: Die Einführung eines bundeseinheitlichen Blutspenderfragebogens wurde empfohlen, um die Sicherheit für Blutspender und Transfusionsempfänger zu erhöhen. Methoden: Die Rückstellungsrate von Vollblutspendern wurde vor (Mai 2010, $n=64$ 735) und nach (Mai 2011, $n=71$ 687) der Einführung eines neuen Blutspenderfragebogens verglichen. Unter Berücksichtigung jahreszeitlicher Schwankungen wurde ein Vergleich mit Hinblick auf die Spendeeinrichtung (stationär vs. mobil), Geschlecht, Spenderart (Erst- vs. Mehrfachspender), Alter und Häufigkeit der medizinischen Rückstellungsgründe durchgeführt. Ergebnisse: Wir fanden eine Erhöhung der Gesamtrückstellungs-/Ausschlussrate von 6,2 auf 8,1\%, unabhängig von der Spendeeinrichtung (stationär: von 6,0 auf 8,5\%; mobil: von 6,2 auf 8,0\%), dem Geschlecht (Frauen: von 7,5 auf 9,9\%; Männer: von 5,1 auf 6,6\%), der Spenderart (Erstspender: von 19,7 auf 24,7\%; Mehrfachspender: von 4,6 auf $6,3 \%$ ) oder dem Alter (18-29 Jahre: von 9,1 auf 11,7\%; 60-71 Jahre: von 5,1 auf 6,6\%) ( $p<0,001$ für alle Analysen). Der vertrauliche Selbstausschluss stieg von 0,08 auf $0,14 \%$ an $(p<0,001)$. Neben dem Risikoverhalten, konnten verschiedene medizinische Rückstellungsgründe als ursächlich identifiziert werden. Schlussfolgerungen: Der neue Blutspenderfragebogen führte zu einer Erhöhung der Rückstellungs-/Ausschlussrate aller Spendergruppen. Da Erstspender, junge Spender und Frauen offensichtlich besonders betroffen sind, sollte ein möglicher Einfluss auf die zukünftige Versorgung mit Blutprodukten beachtet werden. Weitere Langzeitstudien und eine Untersuchung der Spenderakzeptanz sind vor einer endgültigen bundesweiten Einführung notwendig.

\begin{tabular}{ll}
\hline KARGER & ( 2012 S. Karger GmbH, Freiburg \\
1660-3796/12/0391-0017\$38.00/0 \\
Fax+497614520714 \\
$\begin{array}{l}\text { Information@Karger.de } \\
\text { www.karger.com }\end{array}$ & $\begin{array}{l}\text { Accessible online at: } \\
\text { www.karger.com/tmh }\end{array}$
\end{tabular}




\section{Introduction}

The careful selection of blood donors is crucial for donor and transfusion safety and is especially relevant in view of infectious agents. Thus the blood donor questionnaire (DQ) is considered to be a very important tool.

In contrast to other European countries, the various Blood Services in Germany still have their own DQ. Despite the fact that they have to cover all requirements of the German Hemotherapy Guidelines [1] and need to be approved by the Paul Ehrlich Institute (PEI), they differ considerably. Thus in order to establish a nationwide standard, a new national German DQ has been recently developed by the German National Advisory Committee Blood (Arbeitskreis Blut), the Robert Koch Institute and the PEI in cooperation with the German Society of Transfusion Medicine and Immunohematology (Deutsche Gesellschaft für Transfusionsmedizin und Immunhämatologie; DGTI) and the Professional Association of German Transfusion Doctors (Berufsverband der Deutschen Transfusionsmediziner; BDT). Great importance was attached to assess sexual risk behavior, and thus a new question asking for sexual contacts with new partners within the last 4 months was introduced.

In a first evaluation of first-time (FT) donors, it was reported that the new national German DQ would significantly increase deferral rates from 23.5 up to $28.1 \%$ [2]. Thus, it was hypothesized that the new DQ increases transfusion safety, and its nationwide implementation was recently proposed by the Arbeitskreis Blut as the responsible expert committee of the Federal Ministry of Health (Votum 41) [3]. Therefore, the German Red Cross Blood Service Baden-Württemberg Hessen has implemented the new national German DQ on May 1, 2011 with a few informal variations not affecting the general requirements. As there are currently no comprehensive data available, it was the aim of the present study to clarify in a large-scale study whether the new DQ increases defer$\mathrm{ral} / \mathrm{exclusion}$ rates. Considering seasonal variations, analysis was performed with respect to the type of blood collection site, sex, donor status, and age. Furthermore, we determined the frequency of various specific medical reasons for deferral from blood donation comparing our previous with the new national DQ.

\section{Material and Methods}

\section{Data Collection}

All data were generated from the database of the German Red Cross Blood Service Baden-Württemberg - Hessen and were exported to a data warehouse for further analysis. Only allogeneic whole blood (WB) donations, either from mobile or fixed collection sites, were considered for analysis; autologous or directed donations were excluded.

Deferral/exclusion rates in May 1-31, 2010 (previous DQ) were compared with those in May 1-31, 2011 (new national German DQ), reflecting possible seasonal variations. The deferral/exclusion rates were investigated considering WB donations obtained in fixed versus mobile collec- tion sites, sex, donor status (FT versus repeat donor), and donor age (18-29, 30-39, 40-49, 50-59, and 60-71 years). Deferrals due to low hemoglobin values were not considered as this parameter is not affected by the DQ.

For subsequent analysis, the frequencies of various specific medical reasons for deferral/exclusion were calculated. The percentages of deferrals/exclusions and of confidential self-exclusion were calculated based on the total number of individuals willing to donate and on the number of WB donations, respectively. Due to a low absolute number of specific donor deferrals/exclusions, a further analysis with respect to sex, age, donor status (FT vs. repeat donor), or fixed versus mobile collection sites was not possible.

\section{Blood Donor Questionnaire}

The new DQ, which was introduced on May 1, 2011 after approval by the PEI at all collection sites of the German Red Cross Blood Service BadenWürttemberg - Hessen in the two states of Baden-Württemberg and Hessen, was in accordance with the new national German DQ released by the PEI and included only informal variations not affecting the general requirements.

\section{Statistical Analysis}

Statistical analysis was performed with commercially available software for personal computers (SAS software release 9.2; SAS Institute, Inc., Cary, NC, USA). Deferral/exclusion rates, the frequency of various specific medical reasons for deferral/exclusion, and the relative increase of female versus male and FT versus repeat donors were compared between the two observation periods (previous vs. new national DQ). Therefore, a non-parametric binomial test for unrelated samples was performed as the frequency of some medical reasons was small and the assumptions of parametric tests may be violated. $\mathrm{P}$ values $<0.05$ were considered significant.

\section{Results}

The total number of individuals willing to donate allogeneic $\mathrm{WB}$, either at a mobile or a fixed collection site of the German Red Cross Blood Service Baden-Württemberg - Hessen, were: 64,735 (May 1-31, 2010) versus 71,687 (May 1-31, 2011). The overall observed deferral/exclusion rate was $6.2 \%$ $(3,992 / 64,735)$ in May 2010 versus $8.1 \%(5,790 / 71,687)$ in May 2011 ( $\mathrm{p}<0.001)$. Further analysis of deferral rates at fixed and mobile collection sites in 2010 versus 2011 revealed the following: $6.0 \%(290 / 4,865)$ versus $8.5 \%(478 / 5,638)$ and $6.2 \%$ $(3,702 / 59,870)$ versus $8.0 \%(5,312 / 66,049)$ respectively (both $\mathrm{p}<0.001)$. Deferral rates with respect to sex were as follows: $7.5 \%(2,113 / 28,132)$ in 2010 and $9.9 \%(3,164 / 31,854)$ in 2011 of female donors $(\mathrm{p}<0.001)$ as well as $5.1 \%(1,879 / 36,603)$ in 2010 and $6.6 \%(2,626 / 39,833)$ in 2011 of male donors $(\mathrm{p}<0.001)$ were excluded. Comparison of the relative increase revealed a stronger rise in females than in males $(\mathrm{p}<0.001)$. Deferral rates for FT donors were 19.7\% $(1,449 / 7,334)$ in 2010 versus $24.7 \%(1,732 / 7,004)$ in $2011(\mathrm{p}<0.001)$. For repeat donors the respective values were $4.6 \%(2,771 / 60,941)$ in 2010 versus $6.3 \%(4,058 / 64,683)$ in $2011(\mathrm{p}<0.001)$. The relative increase in deferrals of FT donors (increase by $5.0 \%$ ) was found to be stronger than that of repeat donors (increase by $1.7 \%)(p<0.001)$. The deferral/exclusion rates with respect to donor age are summarized in table 1. 
Table 1. Total number of deferrals, exclusions from blood donation per individuals willing to donate $(\%)$

\begin{tabular}{lccc}
\hline \multirow{2}{*}{ Donor age, years } & \multicolumn{2}{l}{ Deferrals, exclusions / individuals willing to donate $(\%)$} & \multirow{2}{*}{ p value } \\
\cline { 2 - 3 } & May 2010 & May 2011 & \\
\hline $18-29$ & $1,529 / 16,845(9.1)$ & $2,138 / 18,287(11.7)$ & $<0.0001$ \\
$30-39$ & $554 / 9,635(5.7)$ & $876 / 10,425(8.4)$ & $<0.0001$ \\
$40-49$ & $852 / 18,076(4.7)$ & $1,230 / 19,999(6.2)$ & $<0.0001$ \\
$50-59$ & $698 / 13,162(5.3)$ & $1,026 / 15,111(6.8)$ & $<0.0001$ \\
$60-71$ & $359 / 7,017(5.1)$ & $520 / 7,865(6.6)$ & $<0.0001$ \\
\hline
\end{tabular}

Table 2. Total number of deferrals, exclusions from blood donation per number of blood donations (confidential self-exclusion) or per individuals willing to donate (all other deferral reasons) (\%), with respect to specific medical reasons in May 2010 (previous DQ) versus May 2011 (new national DQ)

\begin{tabular}{|c|c|c|c|}
\hline Reason for deferral / exclusion from blood donation & $\begin{array}{l}\text { May } 2010 \\
\mathrm{n}(\%)\end{array}$ & $\begin{array}{l}\text { May } 2011 \\
\mathrm{n}(\%)\end{array}$ & $\mathrm{p}$ value \\
\hline \multicolumn{4}{|l|}{ Sexual risk behavior } \\
\hline $\begin{array}{l}\text { Individuals with a significantly increased risk of } \\
\text { transmitting severe infectious diseases } \\
\text { (HIV, HBV, HCV) through blood products }\end{array}$ & $7 / 64,735(0.01)$ & $22 / 71,687(0.03)$ & $<0.05$ \\
\hline $\begin{array}{l}\text { Close/sexual contact to individuals with a } \\
\text { significantly increased risk of transmitting } \\
\text { severe infectious diseases (HIV, HBV, HCV) }\end{array}$ & 4 / 64,735 (0.01) & $56 / 71,687(0.08)$ & $<0.001$ \\
\hline $\begin{array}{l}\text { Unprotected (i.e. not using condoms) sexual contact } \\
\text { with a new partner (for example one-night-stand) }\end{array}$ & $9 / 64,735(0.01)$ & 102 / 71,687 (0.14) & $<0.001$ \\
\hline \multicolumn{4}{|l|}{ Other medical reasons } \\
\hline Intravenous drug abuse & 4 / 64,735 (0.01) & $6 / 71,687(0.01)$ & n.s. \\
\hline Close contact to individuals with hepatitis & 7 / 64,735 (0.01) & 17 / 71,687 (0.02) & n.s. \\
\hline Direct contact to individuals with infectious diseases & 32 / $64,735(0.05)$ & $32 / 71,687(0.04)$ & n.s. \\
\hline Endoscopy & 396 / 64,735 (0.61) & $511 / 71,687(0.71)$ & $<0.05$ \\
\hline Surgery & 197 / 64,735 (0.30) & 217 / 71,687 (0.38) & $<0.05$ \\
\hline Piercing & $140 / 64,735(0.22)$ & $196 / 71,687(0.27)$ & $<0.05$ \\
\hline Inflammation, fever & $156 / 64,735(0.24)$ & $246 / 71,687(0.34)$ & $<0.001$ \\
\hline Diarrhea, persistent stomach pains & 195 / 64,735 (0.30) & $362 / 71,687(0.50)$ & $<0.001$ \\
\hline Treatment with antibiotics & $320 / 64,735(0.49)$ & 467 / 71,687 (0.65) & $<0.001$ \\
\hline $\begin{array}{l}\text { Stay in an area endemic for malaria for less than } \\
6 \text { months, without clinical signs of malaria or } \\
\text { fever of unknown origin }\end{array}$ & $191 / 64,735(0.30)$ & 318 / 71,687 (0.44) & $<0.001$ \\
\hline $\begin{array}{l}\text { Born or had residence in an area endemic for malaria } \\
\text { for more than } 6 \text { months or clinical signs of } \\
\text { malaria or fever of unknown origin after returning }\end{array}$ & 63 / 64,735 (0.10) & $156 / 71,687(0.22)$ & $<0.001$ \\
\hline Transfusion of blood products & 103 / 64,735 (0.16) & 154 / 71,687 (0.21) & $<0.05$ \\
\hline
\end{tabular}

The percentage of confidential self-exclusions increased from $0.08 \%$ in $2010(49 / 60,743)$ to $0.14 \%$ in $2011(95 / 65,897)$ $(p<0.001)$. Comparisons of the frequencies of various specific medical reasons for deferral/exclusion are shown in table 2 . As expected, the frequency of deferrals due to elevated arterial blood pressure were unchanged.

\section{Discussion}

A new national German DQ has been developed in order to set a national standard. Its implementation was proposed [3], but until now there is only few data of 6,500 FT donors available, indicating a high donor acceptance [2]. In this preliminary study the new DQ was assessed to be better understand- able, and there is evidence that the questions were answered more correctly, especially those dealing with sexual risk behavior. Accordingly, deferral/exclusion rates increased significantly among FT donors. Here we report the first detailed large-scale investigation (71,687 WB donations) comparing deferral or exclusion before and after the implementation of the new DQ.

In particular we observed a significant increase of the overall deferral/exclusion rate by $1.9 \%$, corresponding to a total of approximately 1,362 additionally deferred WB donors in May 2011. This applied to both fixed and mobile collection sites. However, referring to the donor sex, we not only found higher initial deferral rates for females, confirming recent studies [4-6], but our data also indicate a more prominent increase in female versus male donors. Therefore additional studies will 
Fig. 1. The new DQ of the German Red Cross Blood Service Baden-Württemberg - Hessen.

Footnote: The new DQ is in accordance with the new national German DQ released by the PEI with the following informal variations: question \#2: 'myocardial infarction' was included as an additional example for cardiovascular diseases under subsection 1 ; question \#4: ' ... or direct contact to individuals with infectious diseases such as measles, mumps, cow pox and influenza' has been added; question \#6: subsections 1 and 2 were summarized into one tick-box instead of two; questions \#7 and \#8 have been exchanged in order; question \#14: subsection 1 'within the last two years' was replaced by 'ever', 'antibodies against Tetanus' was replaced by 'antibodies i.e.: Tetagam $^{\odot}$, Beriglobin ${ }^{\oplus}$; question \#15: 'tissue transplantation' has been omitted and included into question \#30 / subsection 2 , 'dental implantation' has been additionally included; question \#16: subsection 4 of question \#17 ('for females: have you ever had sexual contacts with bisexual males within the last 4 months') has been

\section{DRK-Blutspendedienst Baden-Württemberg - Hessen}

Bitte sorgfältig durchlesen und die zutreffenden Antworten wahrheitsgemäß ankreuzen. (Version 12, Stand 04/11)

Fragen zu Ihrem allgemeinen Gesundheitszustand

1) Fühlen Sie sich krank oder sind Sie krankgeschrieben?

$\square$ ja $\square$ nein

2) Haben oder hatten Sie eine oder mehrere der folgenden Erkrankungen (bitte ggf. unterstreichen):

- Herz-, Gefäß-oder Kreislaufkrankheit (z. B. Bluthochdruck, Thrombose, Embolie, Herzinfarkt, Schlaganfall);

- Erkrankung von Blut, Gehirn, Nerven- oder Lymphsystem, Lunge (z. B. Asthma), Leber, Niere, Magen, Darm oder Haut;

- Allergie, Autoimmunerkrankung, Rheumatisches Fieber, Epilepsie, Zuckerkrankheit, Tumor (z. B. Krebs)?

$\square$ ja $\square$ nein

$\square$ ja $\square$ nein

$\square$ ja $\square$ nein

3) Hatten Sie in der letzten Woche

- einen unkomplizierten Infekt (z. B. Schnupfen, Erkältung, Harnwegsinfekt), $\quad \square$ ja $\quad \square$ nein

- eine zahnärztliche Behandlung,

- eine Verletzung oder einen kleinen operativen Eingriff?

$\square$ ja $\square$ nein

4) Hatten Sie in den letzten $\mathbf{4}$ Wochen Durchfall, anhaltende Bauchschmerzen, Erbrechen, eine Entzündung, Fieber oder Kontakt zu Personen mit ansteckenden Krankheiten z. B. Masern, Mumps, Windpocken, Influenza?

$\square$ ja $\square$ nein

5) Waren Sie in den letzten 4 Monaten in medizinischer Behandlung (im Krankenhaus, beim Arzt, beim Heilpraktiker oder in sonstiger Behandlung)?

$\square$ ja $\square$ nein

6) - Ist Ihnen jemals gesagt worden, dass Sie kein Blut spenden dürfen, sind Sie als Blutspender schon einmal zurückgestellt worden bzw. hat es bei einer früheren Blutentnahme/Blutspende Komplikationen gegeben?

- Spenden Sie auch in anderen Einrichtungen?

7) Üben Sie in den nächsten 12 Stunden Tätigkeiten in Beruf oder Hobby aus, die Sie oder andere gefährden könnten (z. B. Personenbeförderung, Tätigkeit mit Absturzgefahr oder erheblicher körperlicher Belastung)?

$\square$ ja $\square$ nein

8) - Sind Sie alkoholkrank? $\square$ ja $\square$ nein

- Sind oder waren Sie medikamenten- oder rauschgiftabhängig? $\quad \square$ ja $\square$ nein

9) Nur für Frauen:

- Waren Sie jemals schwanger (auch Fehlgeburt, Schwangerschaftsabbruch) oder $\quad \square$ ja $\square$ nein

- waren Sie innerhalb der letzten 2 Jahre schwanger oder

- sind Sie aktuell schwanger oder stillen Sie?

$\square$ ja $\square$ nein

$\square$ ja $\square$ nein

Fragen zu Infektionskrankheiten, die durch Blut übertragen werden können

10) Wurde bei Ihnen jemals

- eine Leberentzündung (Gelbsucht, z. B. Hepatitis $A,-B,-C$ ) festgestellt?

- eine Infektion mit dem Immunschwächevirus HIV-1/2 (AIDS) oder HTL-Virus (HTLV-1/2) nachgewiesen?

$\square$ ja $\square$ nein

$\square$ ja $\square$ nein

11) Wurden Sie in den letzten 4 Monaten akupunktiert?

- Haben Sie sich in den letzten 4 Monaten einer hautverletzenden Maßnahme unterzogen, wie Tätowierung, Piercing, Ohrlochstechen oder kosmetische Behandlung (z. B. Botoxspritzen, permanentes Make-up)?

$\square$ ja $\square$ nein

$\square$ ja $\square$ nein

12) Haben Sie in den letzten 4 Monaten mit einer Person in einem Haushalt gelebt, bei der eine Leberentzündung ( $\mathrm{z}$, B. Hepatitis $\mathrm{A},-\mathrm{B},-\mathrm{C})$ festgestellt wurde?

13) Sind Sie in den letzten 4 Monaten in Berührung mit Blut einer anderen Person gekommen, z. B. über die Schleimhaut (auch Auge) oder durch eine Verletzung mit einem Instrument (z. B. Injektionsnadel/Spritze)?

$\square$ ja $\square$ nein

14) - Haben Sie jemals eine Blutübertragung (rote Blutkörperchen, Blutplättchen, Blutplasma), auch Eigenblut erhalten?

- Erhielten Sie in den letzten $\mathbf{4}$ Monaten Medikamente aus Blutplasma, wie Blutgerinnungsfaktoren oder Immunglobuline (Antikörper z. B. Tetagarn, Beriglobin)?

15) Hatten Sie in den letzten 4 Monaten eine Operation, eine Endoskopie (z. B. Magen-, Blasen-, Darm- oder Gelenkspiegelung), eine Zahnimplantation, eine Katheteranwendung oder wurde Ihnen Gewebe entnommen (Biopsie)?

$\square$ ja $\square$ nein

$\square$ ja $\square$ nein

$\square$ ja $\square$ nein

16) Hatten Sie in den letzten 4 Monaten mit einer neuen Partnerin / einem neuen Partner ungeschützten Intimkontakt (vaginal, oral oder anal ohne Kondom)?

Für Männer: Hatten Sie jemals Intimkontakt mit einem anderen Mann?

Für Frauen: Hatten Sie in den letzten 4 Monaten Intimkontakt mit einem bisexuellen Mann? be needed in order to confirm our findings and investigate the relevant reasons.

Likewise we found increased deferral rates in all age groups even though it seems to be more pronounced for the
18-29 and 30-39 year olds. The reason for this may be the relatively high percentage of FT donors and a higher sexual activity in these age groups; in addition to the data of Offergeld et. al. [2], our results provide evidence that not only de- 
included in this question. Furthermore all subsections of this question have been summarized into one tick-box instead of three; question \#17: under subsection 2 'infections with human T-cell lymphotropic virus (HTLV)' has been included as an additional example for severe infectious diseases, subsection 4 has been transferred to question \#16 (see above); question \#20: subsection 1 'have you ever received fresh cells or tissue/ transplants from animals?' has been omitted and included into question \#30 / subsection 2; question \#22: '...or have you suffered from fever of unknown origin after staying abroad?' has been added; questions \#24 and \#25: 'rikkettsia and epidemic typhus' have been taken out of question \#25 and transferred to question \#24; question \#30: ' $\ldots$ and / or cells or tissue of human or animal origin' has been enclosed under subsection 2 (specific issues have been take out of questions \#15 and \#20, see above); question \#32 (additional question): ' $D o$ you weigh more than 50 kilogram?' has been added. All other questions remained unchanged.

17) Hatten Sie in den letzten 4 Monaten Intimkontakt

- mit einer Person, die länger als 6 Monate außerhalb Europas gelebt hat?

- mit einer Person, die eine schwere Infektionskrankheit (z. B. AIDS, HTLV oder Hepatitis) hat bzw. übertragen könnte?

- für den Sie Geld oder andere Leistungen (z. B. Unterkunft, Drogen) bezahlt haben?

18) - Haben Sie jemals für Intimkontakt Geld oder andere Leistungen (z. B. Unterkunft, Drogen) erhalten?

- Haben Sie jemals Drogen gespritzt oder geschnupft?

- Waren Sie innerhalb der letzten 4 Monate in Haft?

19) Haben Sie in den letzten 4 Monaten Spritzen erhalten, die nicht vom Arzt verschrieben wurden (z. B. Muskelaufbaupräparate)?

$\square$ ja $\square$ nein

$\square$ ja $\square$ nein

$\square$ ja $\square$ nein

$\square$ ja $\square$ nein

$\square$ ja $\square$ nein

$\square$ ja $\square$ nein

$\square$ ja $\square$ nein

20) - Sind Sie in den letzten 12 Monaten nach einem Tierkontakt gegen Tollwutübertragung geimpft worden?

$\square$ ja $\square$ nein

- Erhielten Sie in den letzten 12 Monaten tierisches Serum (z. B. gegen Schlangenbisse)? $\square$ ja $\square$ nein

21) - Sind Sie außerhalb Europas geboren? $\quad \square$ ja nein

- Haben Sie jemals länger als 6 Monate außerhalb von Europa gelebt?

$\square$ ja $\square$ nein

Wenn ja, wo?

Wann?.......

- Waren Sie in den letzten 6 Monaten, auch kurzfristig, im Ausland?

Wenn ja, wo?

22) Wurde bei Ihnen jemals eine Malaria festgestellt oder hatten Sie unklare Fieberschübe nach Auslandsaufenthalten?

$\square$ ja $\square$ nein

23) Haben oder hatten Sie eine Syphilis? $\square$ ja $\square$ nein

24) Haben oder hatten Sie eine Tuberkulose, Osteomyelitis, Toxoplasmose, Q-Fieber, Salmonelleninfektion (Typhus- oder Paratyphus), Fleckfieber oder Rikettsiose?

25) Wurde bei Ihnen jemals eine der folgenden seltenen Erkrankungen festgestellt: Chagas-Krankheit (Trypanosomiasis), Brucellose, Babesiose, Leishmaniose, Lepra, Melioidose, Rückfallfieber, Hasenpest (Tularämie)?

Fragen zu möglichen Rückständen von Arzneimitteln im Blut

26) Haben Sie innerhalb der letzten 4 Wochen Medikamente eingenommen, wie $z$. B. Antibiotika, Schmerzmittel (auch Aspirin, ASS), Mittel gegen Bluthochdruck oder andere? $\square$ ja $\square$ nein Wenn ja, welche?.

Wann etwa war die letzte Anwendung?

27) Haben Sie jemals Medikamente zur Behandlung von Schuppenflechte oder schwerer Akne eingenommen (z. B. Tigason ${ }^{\ominus}$, Neo-Tigason` oder Roaccutane $\left.{ }^{(}\right)$?

28) Wurden Sie in den letzten 4 Wochen geimpft?

Wenn ja, welche Impfung?

Wann?

\section{Fragen nach übertragbaren Erkrankungen des Nervensystems}

29) Wurde bei Ihnen oder einem Ihrer Blutsverwandten die Creutzfeldt-Jakob-Krankheit (CJK) oder die Variante Creutzfeldt-Jakob-Krankheit (vCJK) festgestellt oder bestand jemals ein Verdacht auf eine dieser Erkrankungen?

$\square$ ja $\square$ nein

30) - Sind Sie jemals mit Hormonen der Hirnanhangdrüse, z. B. wegen Wachstumsstörungen, Unfruchtbarkeit, Endometriose behandelt worden?

- Haben Sie jemals Hornhaut (Cornea)-, Hirnhaut (Dura mater)- oder andere Transplantate bzw. Zellen oder Gewebe menschlichen oder tierischen Ursprungs erhalten?

31) - Haben Sie sich vom 01.01.1980 bis 31.12.1996 insgesamt länger als 6 Monate im Vereinigten Königreich Großbritannien und Nordirland aufgehalten?

- Wurden Sie im Vereinigten Königreich Großbritannien und Nordirland nach dem 01.01.1980 operiert oder haben Sie dort eine Blutübertragung (rote Blutkörperchen, Blutplättchen, Blutplasma) erhalten?

Vielen Dank!

$\square$ ja $\square$ nein $04.2011 / 113078$ ferral rates of FT donors but also those of repeat donors are significantly increased. However, as this effect is significantly stronger in FT donors, it may substantially impact on future blood supply, as deferral from blood donation reduces the probability of donor return [4, 7], resulting in definite donor loss [8]. Moreover, this effect may even be intensified by the demographic change [9].

One of the main goals of the new DQ was to better identify 
donors with sexual risk behavior. Our results clearly show that not only the frequency of the confidential self-exclusion but also deferrals due to close or sexual contacts to individuals with a significantly increased risk of carrying transfusiontransmittable infections (TTI) or due to new sexual contacts (not using a condome) within the last 4 months increased markedly. Furthermore, we identified elevated deferral rates due to other medical reasons that could possibly increase the risk of transmitting severe TTI (endoscopy, surgery, piercing within the last 4 months). We also observed an increment of deferrals due to acute illnesses like inflammation, fever, diarrhea, or treatment with antibiotics and for various other reasons such as travel to areas endemic for malaria or even the transfusion of blood products. This indicates that the observed overall rise of donor deferrals must not be explained by an improved identification of individuals with risk behavior alone but by a broad spectrum of reasons. Hence, our results support the hypothesis that the new DQ may be appropriate to improve donor and recipient safety at least in the early phase after its implementation. However, it will be interesting to prove whether this is still valid after several months. In order to finally derive an improvement for blood safety for the future, the genuine impact of the new DQ on donor deferral needs to be characterized in randomized controlled trials. Currently, it cannot be excluded that the observed rise in donor deferral might at least in part be explained by an increased attention due to a new DQ format rather than improved questions, and it would be interesting to clarify whether or not a loss of approximately $1.9 \%$ of WB donors must be expected in Germany in the long run. Nevertheless, additional studies addressing donor acceptance are urgently needed to identify potential adverse effects on non-risk donors, e.g. refraining from further donations because they feel embarrassed. Furthermore, the potential loss of young FT donors in the 'sexual exploration phase' without any classical risk factors needs to be analyzed thoroughly as it may be highly relevant for future blood supply.

In conclusion, the implementation of a new DQ which is based on the new national German DQ resulted in a significantly increased deferral/exclusion of all groups of blood donors. We found evidence that this must not be explained by an improved identification of individuals with risk behavior alone but by a broad spectrum of reasons. As FT, young and female donors obviously are affected in particular, its effect on the future blood supply must be carefully observed.

\section{Acknowledgments}

The authors are grateful to Mr Ronnie Saliger for careful data extraction and subsequent analysis and to Ms. Daniela Griffiths for carefully editing the manuscript.

\section{Disclosure Statement}

The authors declared no conflict of interest.

\section{References}

1 Paul-Ehrlich-Institut: Richtlinien zur Gewinnung von Blut und Blutbestandteilen und zur Anwendung von Blutprodukten (Hämotherapie), Deutscher Ärzteverlag Köln, 2010.

$>_{2}$ Offergeld R, Heiden M, Stoetzer F, Northoff H: Evaluation of a national blood donor questionnaire in Germany. Vox Sang 2010;99(suppl 1):164.

$\checkmark 3$ Mitteilungen des Arbeitskreises Blut des Bundesministeriums für Gesundheit: Verwendung eines einheitlichen Fragebogens für Blut- und Plasmaspender. Bundesgesundheitsbl Gesundheitsforsch Gesundheitsschutz 2010;53:862.
4 Eder A: Evidence-based selection criteria to protect blood donors. J Clin Apher 2010;25:331-337.

$\checkmark 5$ Misje AH, Bosnes V, Heier HE: Gender differences in presentation rates, deferrals and return behaviour among Norwegian blood donors. Vox Sang 2010;98:e241-248.

6 Shaz BH, James AB, Hillyer KL, Schreiber GB, Hillyer CD: Demographic variations in blood donor deferrals in a major metropolitan area. Transfusion 2010;50:881-887.

7 Custer B, Chinn A, Hirschler NV, Busch MP, Murphy EL: The consequences of temporary deferral on future whole blood donation. Transfusion 2007; 47:1514-1523.
8 Zou S, Musavi F, Notari EP, Rios JA, TrouernTrend J, Fang CT: Donor deferral and resulting donor loss at the American Red Cross Blood Services, 2001 through 2006. Transfusion 2008;48:25312539.

9 Greinacher A, Fendrich K, Alpen U, Hoffmann W: Impact of demographic changes on the blood supply: Mecklenburg-West Pomerania as a model region for Europe. Transfusion 2007;47:395-401. 